honorary director of the project will be Prof. D. D. Reid, professor of epidemiology and director of the Department of Medical Statistics and Epidemiology at the London School of Hygiene and Tropical Medicine. Prof. Peter Armitage, professor of medical statistics at the School, will collaborate in this work, and the staff will be partly drawn from existing members of the Department and partly recruited specially for the project.

\section{Films to Teach Science}

Sсноо science departments have, in the past, been hampered by the lack of specialized films suitable for use within the General Certificate of Education syllabus. To coincide with the beginning of the school year and the planning of new science courses, Sound-Services Film Library announces that it has been given distribution rights for the science teaching films of the Physical Science Study Committee produced by Educational Services, Inc. There are fortyeight titles in the $16-\mathrm{mm}$. film series, each film featuring well-known physicists who discuss and carry out experiments in a wide range of subjects. Apart from their use at the General Certificate of Education level, many will be of value to first-year university and technical college students. An illustrated brochure giving a synopsis of each film and an order form with details of hire and purchase charges can be obtained, free of charge, from SoundServices, Ltd., Wilton Crescent, London, S.W.19.

\section{Consolidating Fragile Iron Objects}

THE conservation of objects, in which the iron has been completely converted to oxide, or in which only a small part of the metal remains as a slender core, has long been a problem to archæologists. In the September issue of the Museums Journal (62, No. 2; 1962) Messrs. R. M. Organ and P. Shorer describe an improved method for the consolidation of fragile iron objects. After a survey of the present methods, the authors advocate the use of a microcrystalline wax known commercially as 'Cosmolloid', whereby it is possible to consolidate an unstable object without prior stabilization and elimination of the ferric chloride. The grade $80 \mathrm{H}$ is stated to be the most suitable for the purpose and the practical details are fully described in the paper quoted.

\section{Nuclear Energy Research in Yugoslavia}

THe first volume of papers from the Boris Kidrich Institute of Nuclear Sciences at Vincha appeared in July 1952, and until August 1953 the papers were published in the journal Recueil de travaux de l'Institut de recherches sur la structure de la matière. The title was then changed to the Bulletin of the Institute of Nuclear Sciences 'Boris Kidrich', Belgrade, and the Bulletin appeared annually with one volume per annum, except for 1953 and 1961, when two volumes per annum were published. During 1961 the number of papers submitted exceeded the possibility of the continuance of a standard volume per year, and accordingly with the commencement of Volume 13, 1962 , the Bulletin is to be issued quarterly. The first issue (13, No. 1; April 1962) contains six articles, including a description of attempts made to measure the radiation of the $R A$ reactor at Vincha by chemical dosimeters, and details of the ' $2 k C$ ' cobalt-60 radiation unit of the Boris Kidrich Institute at Vincha with its components-source, container, driving mechanism, radiation room, remote-control table, etc.
The Leopoldina German Academy of Science

The Deutsche Akademie der Naturforscher Leopoldina, Halle, recently elected the following new members in the sections indicated: Mathematics, Prof. B. N. Delaunay (Moscow), Prof. Karl Marguerre (Darmstadt), Prof. Hans Reichardt (Berlin), Prof. I. M. Vinogradov (Leningrad); Physics, Prof. Hans Falkenhagen (Rostock); Chemistry, Prof. Oskar Glemser (Göttingen), Prof. Ulrich Hofmann (Heidelberg), Prof. František Sorm (Prague), Prof. Friedrich Wessely (Vienna), Prof. Georg Wittig (Heidelberg), Prof. S. Ju. Junusov (Taschkent); Physical Chemistry, Prof. Klaus Schäfer (Heidelberg); Botany, Prof. Paul Collander (Helsinki), Prof. Harry Godwin (Cambridge), Prof. Roger Heim (Paris), Prof. Bruno Huber (Munich), Prof. Poul Larsen (Bergen), Prof. Wilhelm Menke (Cologne), Prof. Heinrich Walter (StuttgartHohenheim), Prof. Frits W. Went (St. Louis); General Biology, Prof. Ivan Málek (Prague), Prof. A. I. Tolmatchev (Leningrad).

\section{Geology of the South-West of England}

IN January 1956 a conference was held at the University of Exeter of geologists and geomorphologists working in the south-west of England. It was discovered that there was a real need for contact between the scattered workers who were pioneering new lines of attack on the little-known geology of this difficult region. A great deal of progress has been made in the past six years to which the subsequent conferences held in 1958, 1960, 1961 and 1962 have made a useful contribution. At the last conference a decision was taken to set up a properly constituted society to hold regular annual conferences each January and to publish the abstracts of the conference proceedings. Abstracts of the proceedings of the second, third and fourth conferences had been published by the kind offices of the Royal Geological Society of Cornwall. The new society is named the Ussher Society in honour of W. A. E. Ussher (18491920), an officer of the Geological Survey of Great Britain who made fundamental contributions to several aspects of the geology and geomorphology of the region.

The first conference of the Ussher Society as such will be held at the University of Exeter during January 2-4, 1963. The secretary is Mr. M. Stone, of the Department of Geology, University of Exeter.

\section{The Night Sky in November}

FULL moon occurs on Nov. 11d. 22h. 04m. ए.T. and new moon on Nov. 27d. 06h. 30m. The following conjunctions with the Moon take place: Nov. 4d. 19h., Saturn $0 \cdot 6^{\circ}$ S.; Nov. 6d. 18h., Jupiter $1^{\circ} \mathrm{N}$.; Nov. $18 \mathrm{~d} .09 \mathrm{~h} .$, Mars $0.7^{\circ} \mathrm{N}$. Morcury and Venus are too close to the Sun for easy observation. Mars rises at $22 \mathrm{~h} .20 \mathrm{~m} ., 21 \mathrm{~h} .55 \mathrm{~m}$. and $21 \mathrm{~h} .25 \mathrm{~m}$. on Nov. 1 , 15 and 30 , respectively. It is at a distance of 106 million miles on November 15, and its stellar magnitude is +0.5 . Conditions are becoming more favourable for observation. Jupiter sets at $0 \mathrm{~h}$. $40 \mathrm{~m}$., $23 \mathrm{~h}$. $50 \mathrm{~m}$. and $22 \mathrm{~h}$. $50 \mathrm{~m}$. at the beginning, middle and end of the month, respectively. It is in Aquarius, its stellar magnitude is $-2 \cdot 1$ and its distance from the Earth in the middle of the month is $\mathbf{4 3 6}$ million miles. Saturn is in Capricornus, setting at $22 \mathrm{~h} .00 \mathrm{~m}$., $21 \mathrm{~h} .10 \mathrm{~m}$. and $20 \mathrm{~h} .15 \mathrm{~m}$. on Nov. 1,15 and 30 , respectively. Its stellar magnitude is $+0 \cdot 9$ and its distance from the Earth on November 15 is 947 million miles. Occultations of stars brighter than magnitude 6 are as follows, observations being made 